\title{
The Environmental Implication of Gas Flaring in Sapele Community of Delta State, Nigeria
}

\author{
Oseh Jeffrey Onuoma ${ }^{1,}$, Oguamah Ifeanyi Alex ${ }^{2}$, Oluwagbenga Omotara Olawale ${ }^{1}$, \\ Adeyi Abel Adekanmi ${ }^{1}$ \\ ${ }^{1}$ Department of Chemical and Petroleum Engineering, Afe Babalola University, Ado Ekiti (ABUAD), Nigeria \\ ${ }^{2}$ Department of Petroleum Engineering, Federal University of Technology, Owerri (FUTO), Nigeria
}

\section{Email address:}

osehjo@abuad.edu.ng (O. J. Onuoma), uchelex@gmail.com(O. I. Alex), oluwagbenga12@yahoo.com (O. O. Olawale), abeladeyi@gmail.com (A. A. Adekanmi)

\section{To cite this article:}

Oseh Jeffrey Onuoma, Oguamah Ifeanyi Alex, Oluwagbenga Omotara Olawale, Adeyi Abel Adekanmi. The Environmental Implication of Gas Flaring in Sapele Community of Delta State, Nigeria. International Journal of Oil, Gas and Coal Engineering. Vol. 3, No. 5, 2015, pp. 60-65. doi: 10.11648/j.ogce.20150305.11

\begin{abstract}
Despite longstanding laws against gas flaring in Nigeria which is the burning of natural gas during oil extraction, and shifting deadlines to end the practice, the activity continues, with serious environmental and health consequences for people living nearby. In the Niger Delta, especially in the Sapele community of Delta State where most of the flaring takes places, residents living near gas flares complain of respiratory problems, skin rashes and eye irritations, as well as damage to agriculture due to acid rain. The major environmental implications considered in this study are environmental pollution, and ecological disturbance or destruction. Several visitations to the neighboring communities like Amukpe and Ugberikoko Communities of Delta State adjacent to most gas flare locations were carried out to ascertain any existence of common environmental hazards. Data were gathered through a well-designed survey and direct and first-hand observation from the flared environment. Different samples at various proximities from the gas flare locations were taken and measurements and experimentations were logically carried out. The result obtained in this study showed some variations away from the flare point in the flow stations. The temperature tends to normalize at $31^{\circ} \mathrm{C}$. This result shows a surface temperature elevation of about $1.8{ }^{\circ} \mathrm{C}$ above mean normal daily temperature within a distance of $400 \mathrm{~m}$ radius away from the flare point. Hence the thermal equilibrium within Sapele localities has been altered. Soil $\mathrm{P}^{\mathrm{H}}$ is near neutral (6.62-7.88) away from the flare points and the average high soil moisture content ranges between $(92 \%-94 \%)$ as against $96 \%$ for the flare points and control distance. These values portray a good omen for these communities under investigation. However, less than or closer to $400 \mathrm{~m}$ from the flare point, residents are likely to be exposed to gas flaring effects. Nigerian oil and gas industries should design and develop a gas compression and re-injection facility with the sole objective of achieving zero flaring. The facility should also be designed to ensure export capability and to compress wet and dehydrated gas to gas re-injection wells. Finally, residential buildings should be sited at least $1 \mathrm{~km}$ away from the flare point.
\end{abstract}

Keywords: Gas Flaring, Soil PH, Soil Temperature, Soil Moisture Content, Rain Water

\section{Introduction}

Gas flaring is the burning of natural gas that is associated with crude oil when it is pumped up from the ground. In petroleum-producing areas where insufficient investment was made in infrastructure to utilize natural gas, flaring is employed to dispose of this associated gas [1]. In Nigeria, when oil companies began production in the 1960's, the cheapest way to separate the identified product, crude oil, from the associated natural gas was to burn the gas [2]. Also chemical factories, oil refineries, oil wells, rigs and landfills, gaseous waste products and sometimes even non-waste gases produced are routed to an elevated vertical chimney called a gas flare and burnt off at its tip, this is called gas flaring [3]. Waste gases are subjected to such a process either because the gases are waste or it is difficult to store and transport them. Non-waste gases are burnt off to protect the processing equipment when unexpected high pressure develops within 
them. Gas flaring in oil rigs and wells contribute significantly to greenhouse gases in our atmosphere [4].

The discovery and extraction of natural resources have brought different consequences to countries that are endowed with such resources. While some of these nations have become economically strong and self-sustaining, others have been drawn into serious economic hardships and conflicts. Proponents of the resource have it that the citizens of these countries suffer from abject poverty, environmental damages, pollutions, diseases, illiteracy and score very low on the United Nations Human Development Index [5].

The Niger Delta region, where Nigeria Current huge Oil and Gas resources are located, with the Niger Delta as the unifying feature has remained a source of global interest. With openness to the Atlantic Ocean and watercourses with access to the sea and rivers such as the Benue and Niger Rivers, the Niger Delta embodies some of the major coastal upwelling sub-ecosystems of the world and is an important center of marine biodiversity and marine food production ranked among the most productive coastal and offshore waters in the world [6]. However, pollution from domestic and industry sources, over-exploitation of Oil and Gas resources and poorly planned and managed communities and coastal developments and near-shore activities are resulting in a rapid degradation of vulnerable land, coastal and offshore habitats and shared living marine resources of the region putting the economies and health of the populace at

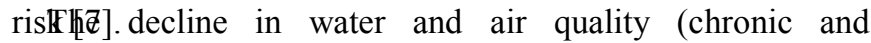
catastrophic) from land and sea-based activities especially industrial i.e. flaring/power plants, agricultural, urban and domestic sewage run-off, eutrophication and gas flaring have been identified as a major Trans-boundary environmental problem by communities in the region. Mainstream economics of the neoclassical kind was not developed primarily to deal with environmental problems [8]. When facing a new category of problems, it therefore also seems reasonable to consider alternatives to the neoclassical paradigm. The limited reversibility or irreversibility of many environmental impacts is one reason to question conventional economic reasoning, which generally assumes that everything can be traded against everything else in monetary terms. Secondly, ethical and ideological issues become accentuated in relation to environmental problems. Even if it were accepted that impacts can be traded against each other in one-dimensional, monetary terms, the price at which such trading should occur is always open to debate. The idea of correct prices for purposes of resource allocation suggested by conventional cost-benefit analysis becomes less convincing, if not absurd. Why those prices? What right does one have, as an economist, to define so-called correct prices or correct rules for valuing environmental impacts or other impacts in monetary (or other one-dimensional) terms? There are ethical reasons to suggest, for instance, an infinite price for irreversible degradation of the natural resource base available to future generations. And, as already indicated, irreversible impacts are the common case rather than the exception. The burning of coal, oil or natural gas is an irreversible process [9].
Pollution of air, water and soil is often irreversible or difficult to reverse, and the same is true of land exploitation for various purposes, or interference with ecosystems. Environmental and socio-economic issues become business issues. Thus, what is good for the economy is equal to what good for the environment [10]. At a pragmatic level, there are some obvious reasons for environmental management study. The traditional view about regulation ecology and economy sounded like ecology versus economy. Social benefits that demand strict environmental standard confronts industry's private costs, cost of prevention, and clean-up faced reducing of competitiveness and price increase. Fortunately, make a business in the real world of dynamic competition, in the static world with many economic theories. Thus, it can be concluded that static view of ecological regulation is incorrect today. Moreover, it is not simply enough for companies to have only resources. Using resources productively is what makes for successful competitiveness today [11].

Companies and states can improve resource productivity by providing existing products more efficiently or by making products more valuable for customers, products customers are willing to pay for [12]. Some researchers deem that industry's pollution today means inefficiency. Really, when scarp, harmful substances, or energy forms are discharged into the environment as pollution, it is sign that resources have been used incompletely, inefficiently, or ineffectively [1 However, it is so naïve that most companies existed to overlook their policy into environmental compliance fast. Unfortunately, traditional ways of business dominates rooted tightly in company's top management conscience. Moreover, several years ago, most businesses hoped that the environmental issues would disappear, but till date it has still not; it has only gained more importance [13]. Some scholars believe that technology will solve environmental problems and can replace natural capital by profit maximization in resource utilization (weak sustainability- neoclassical economics paradigm), while others believe that it is only to an extent that technology can replace natural capital (strong sustainability-ecological economics paradigm) [14].

All these world trends claimed from the firms to consider environmental issues in long-term perspective. How should companies be motivated into environmental friendly policy and who should determine ecological standard: government, policy makers or companies themselves? This is real tight challenge toward sustainable development.

\section{Methodology}

The employed technique link both theoretical framework and empirical finding in appropriate way including the choice of research design and formulation, method of data collection and laboratory works undertaken. Samples used for this study were obtained in the gas flaring locations of Amukpe and Ugberikoko Areas of Delta State, Nigeria. Parameters analyzed were Soil PH, Soil moisture content, rain water (acid rain) and the soil temperature. 


\subsection{Data Collection Methods}

Comprehensive lists of all gas flare locations were made. Several visitations were made to most of the various under listed gas flare locations in a bid to achieve my mentioned objectives. Primary method of data collection was employed for this study. Data were gathered through a well-designed survey, and direct and first-hand observation of the environment (landed and water bodies). Different samples at various proximities from the gas flare locations were taken and measurements were recorded. The samples obtained from the flared areas were at a distance which ranges from $400 \mathrm{~m}, 800 \mathrm{~m}, 1200 \mathrm{~m}, 1600 \mathrm{~m}$ and $2000 \mathrm{~m}$. The operating temperature within the $400 \mathrm{~m}$ - flared areas of Amukpe and Ugberikoko were approximately $37{ }^{\circ} \mathrm{C}$ and $39{ }^{\circ} \mathrm{C}$ respectively.

\subsection{Data Analyses}

The parameters monitored at each sampling location included: Rain water from the flares, Soil temperature, Soil $\mathrm{P}^{\mathrm{H}}$, and Soil moisture content. Standard measurements for each parameter were carried out as follows:

\subsubsection{Rain Water Measurement}

Clean acid-free glass bottles were used to collect bulk samples of rain that had fallen during the previous day. The samplers were placed at distances of $400 \mathrm{~m}, 800 \mathrm{~m}$, and 1200 $\mathrm{m}, 1600 \mathrm{~m}$, and $2000 \mathrm{~m}$ from the flare point. The funnel was covered with a plastic net to prevent collection of windblown debris. Each bottle was placed on a stand 1.3-1.5 m above ground level. The collected rain water samples were analyzed in the laboratory to test for their acidity or alkalinity using a $\mathrm{P}^{\mathrm{H}}$ meter as recommended by Department of Petroleum Resources (DPR) and Federal Ministry of Environment. The electrode was calibrated with buffer solution i.e. distilled water + buffer powder. This helped to stabilize the electrode to a neutral value of 7.0 when the electrode was dipped into the buffer solution. The electrode was dipped into the rain water sample and allowed to stay in the sample for 30 seconds and the readings were taken after 30 seconds.

\subsubsection{Soil Temperature Measurement}

The temperature of each soil sample was determined using Mercury-in-glass thermometer, which was placed $2-3 \mathrm{~cm}$ into the soil. The thermometer was left in the soil for about 5 minutes to stabilize and read before withdrawal. This was done at the site of collection.

\subsubsection{Soil Moisture Content Measurement}

The soil moisture content was determined using OHAUS Scout Pro $6000 \mathrm{~g}$ weighing balance. $5 \mathrm{~g}$ of each soil sample was heated in a hot air Universal Oven for $3 \mathrm{hrs}$ at $105{ }^{\circ} \mathrm{C}$ until a constant weight was obtained. The difference between the initial weight and the consistent final weight obtained was taken as the weight of the moisture content in the soil and was determined as follows: Drying of a suitable container, cooled in a desiccator and weighed. The samples were thinly spread in the container and weighed rapidly. It was then dried in an air-circulation oven at $105^{\circ} \mathrm{C}$ to constant weight for 3 hours and cooled in a desiccator and weighed. The differences in the weight samples were then calculated with the parameters below:

$$
\begin{aligned}
& \text { Moisture }(\%)=\frac{\text { loss in weight on drying }(g)}{\text { initial sample weight }(g)} * \frac{100}{1} \\
& \text { Moisture }(\%)=\frac{w 3}{w 2} * \frac{100}{1}
\end{aligned}
$$

Where,

$\mathrm{W}_{3}$ is the loss in weight on drying $(\mathrm{g})$

$\mathrm{W}_{2}$ is the initial weight of the sample $(\mathrm{g})$

\subsubsection{Soil pH Measurement}

The $\mathrm{P}^{\mathrm{H}}$ of the various soil samples were determined from supernatant obtained after 1:1 (w: v) mixture of the soil samples were made with sterile distilled de-ionized water. The $\mathrm{pH}$ was determined using a METTLER TOLEDO LE407 $\mathrm{P}^{\mathrm{H}} ; \mathrm{P}^{\mathrm{H}} 0 \ldots 14.0 ; 80{ }^{\circ} \mathrm{C} \mathrm{P}^{\mathrm{H}}$ meter with a combined glass electrode as follows: $30 \mathrm{~g}$ of soil into the glass petri dish was weighed and $30 \mathrm{~g}$ of distilled water was added to the soil sample and stirred to obtain slurry and then covered with a watch glass. The sample stood for a minimum of 1 hour, stirring every 10 to 15 minutes to allow the $\mathrm{P}^{\mathrm{H}}$ of the soil slurry to stabilize. Immediately before immersing the electrode into the sample, the sample was well stirred with a glass rod and the electrode was placed into the soil slurry solution and the beaker was gently turned to make good contact between the solution and the electrode. The electrode was carefully placed only into the slurry and not place into the soil to obtain accurate result. After 1 hour, the temperature of the sample was stabilized. The temperature of the sample was measured and recorded. The above procedures were repeated four times to obtain results on the different locations covered. The electrode requires immersion 30 seconds or longer in the sample before reading to allow the meter to stabilize.

\section{Results and Discussion}

\subsection{Rainwater Analysis}

The result on the analysis carried out on rain water to determine the effects of gas flaring is shown in Fig. 1. The result shows that the $\mathrm{P}^{\mathrm{H}}$ values were generally above 5.6 (WHO 1970 limit for rain acidity) for the two gas flare locations (Location A and B) prior to the distances of sampling from the flare locations (400 m away from flare locations). Hence, the residents are less likely expose to to water-borne diseases and the aquatic lives in these locations are not utterly destroyed.

\subsection{Soil Temperature}

The result from Fig. 2 shows that the closer a sampling point was to the flare, the higher the soil temperature. The 
soil temperature was taken $400 \mathrm{~m}$ away from the flare point and the values obtained were close to the control value used. This means that the gas flared is less harmful to the people living within the range of $400 \mathrm{~m}$ away from the flare point. A higher temperature beyond $100 \mathrm{~m}$ from the flare tip will affect the survival of microbes and germination of plants. The soil temperature taken in the morning was approximately $1{ }^{\circ} \mathrm{C}$ lower than that taken late afternoon or evening. Effect of vegetation cover was found to lower the soil temperature by as much as $4^{\circ} \mathrm{C}$.

\subsection{The Soil $P^{H}$}

The result from Fig. 2 show that $\mathrm{P}^{\mathrm{H}}$ values obtained from the flare points were near neutral $(6.62-7.88)$. These $\mathrm{P}^{\mathrm{H}}$ values obtained shows that the environment at that period is safe for any farming activities or fishing activities. Low $\mathrm{P}^{\mathrm{H}}$ values at the flare points could be attributed to the acidic oxides produced by the flaring. At $\mathrm{P}^{\mathrm{H}}$ lower than 5 , most fish eggs will not hatch and lower $\mathrm{P}^{\mathrm{H}}$ values can kill adult fishes.
As lakes and rivers become more acidic, aquatic life is sent into extinction and biodiversity is reduced.

\subsection{Moisture Content}

The result from Fig. 2 show that moisture content also increased away from the flare site. The lowest soil moisture content was observed at $1600 \mathrm{~m}$ distance from the flare site of location A and $800 \mathrm{~m}$ from the flare site of location B having at least higher percent while the control had the highest percent of moisture in the soil. As expected, the hottest spot was nearest to each flare jet and it gradually decreased away from the flare point. The heat produced from the flaring point is highest at the flare point as expected. The low moisture content close to the flaring point is a direct effect of the heat. All the soil samples examined had very high moisture content in soil at $400 \mathrm{~m}, 800 \mathrm{~m}, 1200 \mathrm{~m}, 1600$ $\mathrm{m}$ and $2000 \mathrm{~m}$ respectively. The $2000 \mathrm{~m}$ soil samples and controls have higher moisture content.

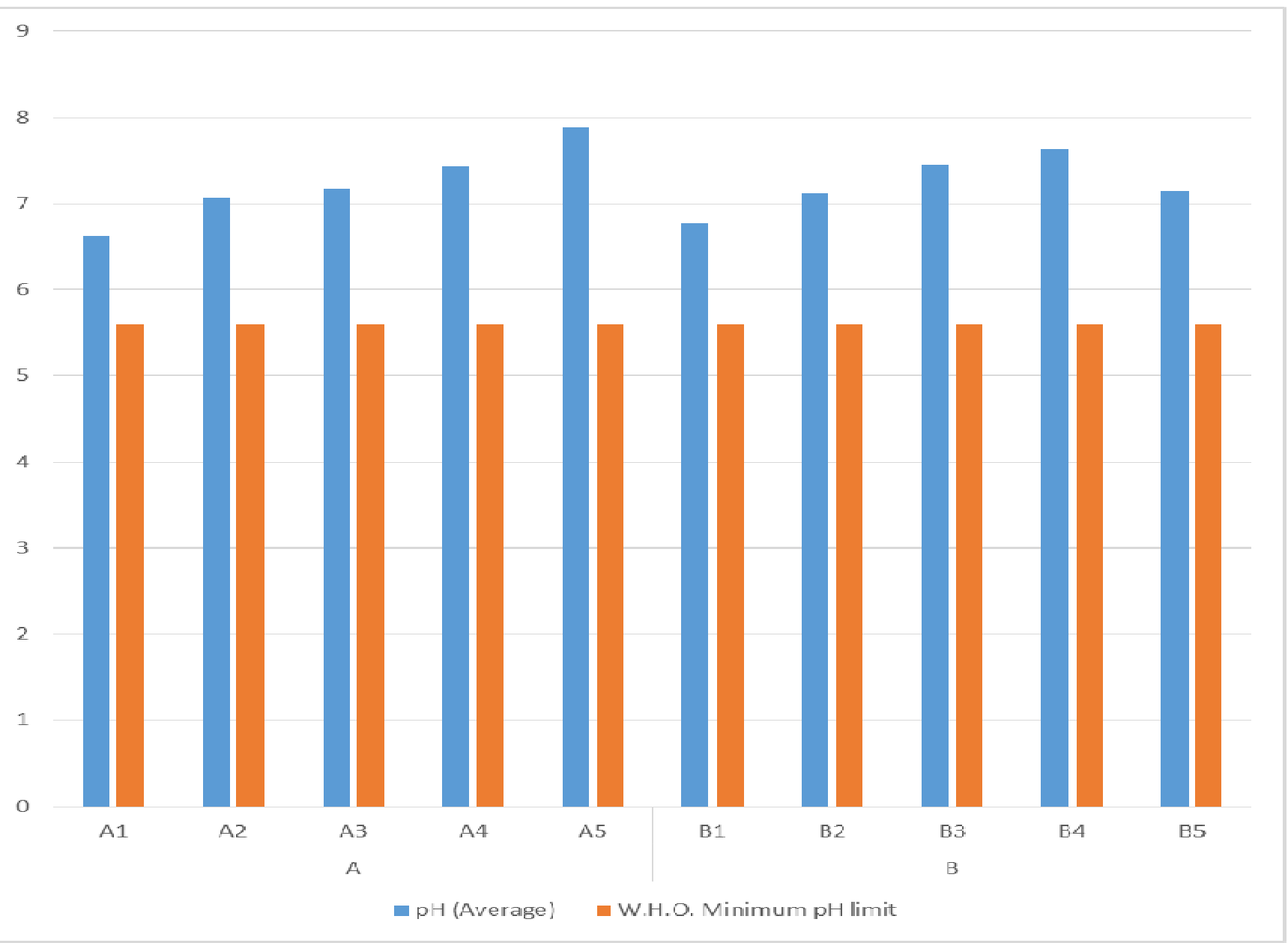

Fig. 1. The Average PH of rainwater samples taken from the gas flares locations. 


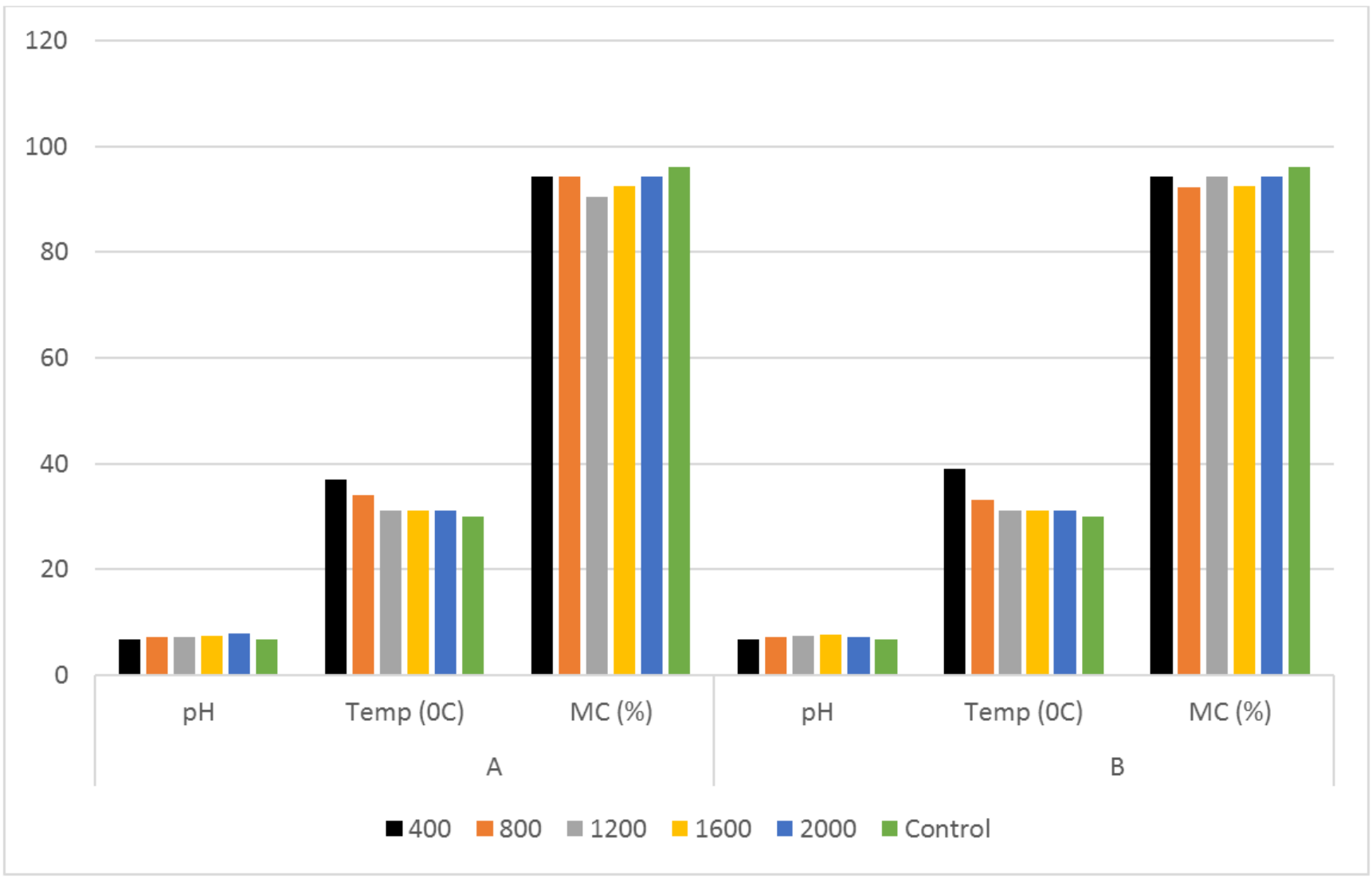

Fig. 2. The $P^{H}$, Temperature and Moisture Content of the various samples taken from gas flare locations A and B.

\section{Conclusions}

The study focused on the environmental implication of Gas flaring in Sapele Community of Delta State, Nigeria and the safety of residents living within these gas flare locations. The results obtained under environmental analysis showed that the $\mathrm{P}^{\mathrm{H}}$ of rainwater $(>5.6)$ in the two locations sampled were within the regulation limits for the two locations considered. In addition, the average soil temperature of ( 37 ${ }^{\circ} \mathrm{C}$ and $39{ }^{\circ} \mathrm{C}$ ) as against $30{ }^{\circ} \mathrm{C}$, is above the control limit. Soil $\mathrm{P}^{\mathrm{H}}$ of $(6.62-7.88)$ as against 6.60 and high moisture content of $(92 \%-94 \%)$ as against $96 \%$ for the $(400 \mathrm{~m}, 800 \mathrm{~m}, 1200 \mathrm{~m}$, $1600 \mathrm{~m}$ and $2000 \mathrm{~m}$ ) were slightly above the control limit. All results recorded during this study of the producing oil community (Sapele) in Delta state from the sampling point portray good forecast for these communities. The results obtained shows that water bodies in these environments (400 $\mathrm{m}+$ perimeters away from the flare locations) are less contaminated by the effect of gas flaring which means there are possibilities that fishes and other aquatic lives can survive in this region (400 $\mathrm{m}$ away from flare locations).

Moreover, the acidic nature of the soil also has attendant effect on the soil usually used for agricultural purposes but there was no trace of acidity from the soil experiment carried out. This means that the soil is good for agricultural practices. Farming/planting activities can be carried out regardless of the flared gas.
Judging from the results obtained, it could be concluded that residents within $400 \mathrm{~m}$ or more away from the flare point are not likely subjected to environmental hazards caused by gas flaring and gas flaring activities in these regions. However, less than or closer to $400 \mathrm{~m}$ from the flare point, residents are likely to be exposed to gas flaring hazards.

\section{Recommendations}

It is advised to employ flashed gas compressors for further Liquefied Petroleum Gas (LPG) recovery and thus more cash income and reducing environmental pollution. Another process is using gas-liquid ejectors to utilize flashed gases.

Finally, residential buildings should be sited at least 1kilometer away from the flare point.

\section{References}

[1] JINN, Gas Flaring in Nigeria: an Overview, Justice in Nigeria Now. April 2010. Available www.justiceinnigerianow.org

[2] A. A. Arowolo and I. J. Adaja. "Trends of natural gas exploitation in Nigeria and its implications on the socio-economic stability and governance," 35th Nigerian Statistical Association annual conference. 2011.

[3] A. O. Ajugwo "Negative Effects of Gas Flaring: The Nigerian Experience." Journal of Environment Pollution and Human Health 1.1 (2013): 6-8. 
[4] T.J. Ayoola. "Gas flaring and its Implication for Environmental Accounting in Nigeria," Journal of Sustainable Development; 4(5): 244-250, 2011.

[5] United Nations Development Programme. (2006) "Human Development Report of United Nations Development Programmed, -Niger Delta human development report $<$ http://web.ng.undp.org/reports/nigeria_hdr_report.pdf $>$ pp. $11,2006$.

[6] M. Olukoya. "Gas flaring and the preservation of Biodiversity in the Niger Delta" in Agbabu (ed.). Environmental Issues in Niger Delta Region of Nigeria. Johnson Publishers, Lagos, 2008.

[7] R.U. Ayres. "Sustainable economics: where do we stand? Ecological economics". 6, 7: 281-310, 2008.

[8] H.E. Daly. "Ecological Economics 6, Allocation, distribution, and scale: toward an economics that is efficient, just, and sustainable", pp. 185-194, 1992.

[9] H.E. Daly. "Beyond growth-the economics of sustainable development”. Beacon Press, Boston, 1996.
[10] E.C. Ubani and Onyejekwe, I. M. Onyejekwe. "Environmental impact analysis of gas flaring in the Niger delta region of Nigeria" American J. of Scientific and Industrial Research; 4(2), 246-252, 2013.

[11] Effiong, S.A. Effiong and Etowa, U.E. Etowa. "Oil spillage cost, gas flaring cost and life expectancy rate of the Niger Delta people of Nigeria", Advances in Management \& Applied Economics, 2(2), 211-228, 2012.

[12] A.O. Tolupe. "Oil exploration and environmental degradation: the Nigeria experience", International society for Environmental Information Science. 4(4), 34-36, 2004

[13] C.K. Wilber and Harrison, R.S. Harrison. "The methodological basis of institutional economics: pattern model, storytelling and holism". Journal of Economics. 1, 2: 61-89, 1978.

[14] A. Marshall. "Principles of economics, 8th edition. Macmillan and Co, ltd. London, 1920. 